\title{
DIAMONDIFEROUS MEGACRYSTAL GARNET AND ORTHOPYROXENE FROM LIQHOBONG, LESOTHO
}

\author{
O'Brien* HE, Birnie AC and Spencer RG \\ Geological Survey of Finland, Espoo, Finland \\ Cliffs Natural Resources PTY LTD, WA, Australia, formerly Kopane Diamonds, London, U.K. \\ Grosvenor Exploration and Mining Services, St. Albans, U.K
}

\section{INTRODUCTION}

The Liqhobong Main kimberlite pipe is an archetypal Group I, olivine-rich, volcaniclastic kimberlite filled vent with high olivine contents and abundant pelletal lapilli in some of the 4 volcanic phases identified. The satellite pipe has slightly less olivine, but is more enriched in other mantle indicator minerals. Initial conventional diamond indicator mineral counts and compositions from both pipes however, did not seem to match with the minable diamond grades realized in the mine project. As an ultimate test of the diamond source material at Liqhobong, exceptional samples of mantle-derived minerals from the Satellite and Main pipe, up to $1 \mathrm{~cm}$ in size, with diamonds protruding from the side of the host grains, were analyzed by electron microprobe to ascertain the pedigree of the mantle mineral hosts. In all, 25 single or multiple grain samples were analyzed, all with attached small $(0.25-1 \mathrm{~mm})$ diamonds, many of gem quality (Fig. 1). All suspicions were that the dominant orangebrown garnet grains would be eclogitic in composition and that the accompanying clear grayish grains would be some type of "bleached" eclogitic omphacitic clinopyroxenes.

\section{Results}

Of the 25 samples, 19 are composed wholly or in part of megacryst composition pyrope, G1 in the garnet classification scheme of Dawson \&

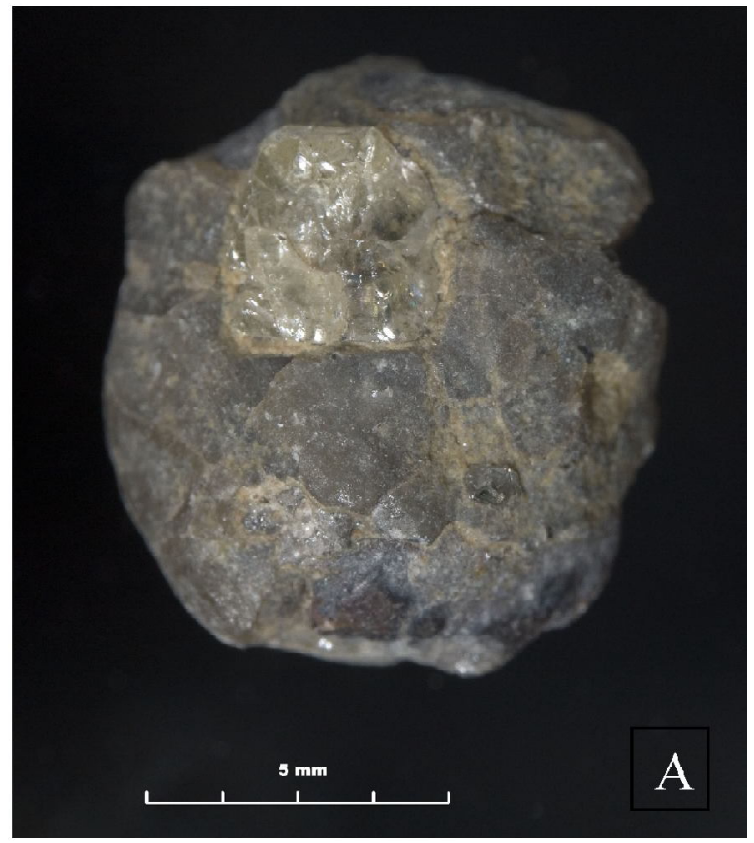

Figure 1. Above and next page. Liqhobong megacrysts from a mixed population of Main and Satellite kimberlite. As such it is impossible to determine which pipe the grains are derived. Note that the scale varies from image to image. A. GD-01, dominantly opx in this view, garnet visible on the bottom of the image. B. GD-03, no opx in this grain, 1 larger diamond at top and numerous smaller diamonds protruding elsewhere from the grain. C. GD-10 is the lowest TiO2 grain of the non-peridotite group and consequently straddles the G1G4 boundary. D. GD-14 has been included for contrast as it is a high $\mathrm{Cr}$ (10.2 wt\%) lherzolitic (G9) grain. E. GD-25 Opx-G1 garnet and diamonds, all of similar grain size comprise this microxenolith.

Stephens (1975) using the parameters set out in Grütter et al., 2004 (Table 1); none are eclogitic. All of the pyroxenes are Ca-poor, low Al orthopyroxene (opx); none show any solid 

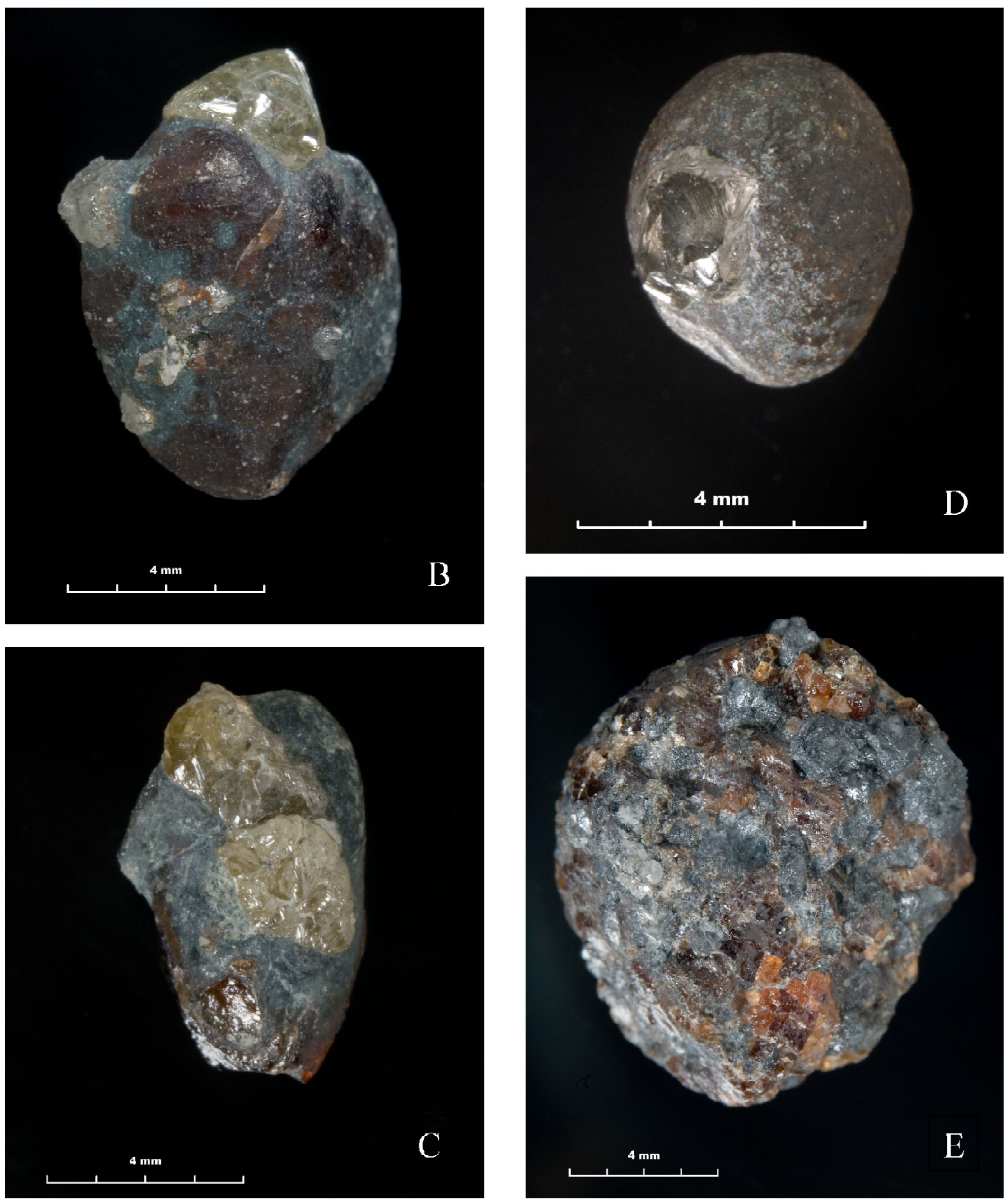


\section{0 $^{\text {th }}$ International Kimberlite Conference, Bangalore - 2012}

solution toward or exsolution lamella of omphacitic clinopyroxene (Table 1). In addition, two host grains are lherzolitic pyropes (G9) and a third pyrope is at the G1-G9 border with $3 \mathrm{wt} \%$ $\mathrm{Cr} 2 \mathrm{O} 3$. Two samples contain only opx and two samples contain coexisting G1 garnet and opx. Two of the opx grains contain sulfide-rich blebs that comprise intergrowths of a hydrated Fe-rich silicate phase and sulfides varying from $\mathrm{Cu}$ to $\mathrm{Ni}$ rich, suggesting exsolution after crystallization of a mono-sulfide + silicate liquid or fluid.

\section{DISCUSSION}

Compositional ranges of the Liqhobong diamondiferous $\mathrm{G} 1$ garnets in $\mathrm{wt} \%$ are $\mathrm{TiO} 20.4-$ $0.8, \mathrm{Cr} 2 \mathrm{O} 3$ 0.15-1.0, $\mathrm{CaO} 4.2$ to $3.7(\mathrm{Ca} / \mathrm{Ca}+\mathrm{Mg}$ $0.12-0.14$ ) and a mg range of 69-80 (Table 1 ). The four opx grains studied have identical compositions within error of the microprobe data with (in wt \%): $\mathrm{CaO} 0.82, \mathrm{Al} 2 \mathrm{O} 30.85$ and $\mathrm{mg}$ of 88-90 (Table 1). There is no overlap of these garnet and opx compositions with those from unusual eclogites from the Zero kimberlite, representing the most opx-rich eclogites so far reported (Schmickler et al., 2004) wherein opx has exsolved from clinopyroxene. Instead, the Liqhobong diamondiferous G1 garnets and orthopyroxene compositions fit almost exactly those of a unique enstatite megacryst containing coexisting lherzolitic and megacryst composition pyrope discovered in material from the Weltevreden kimberlite, SA (Meyer et al., 1979). All but two of the Liqhobong garnet grains reported here fit well into the megacryst composition field in $\mathrm{TiO} 2 \mathrm{wt} \%$ versus $\mathrm{mg}$ as defined in Grütter et al., 2004 (Fig. 2).

\section{CONCLUSIONS}

Implications of this discovery are significant in that evaluation of a kimberlite for diamond content cannot ignore the potential of G1 garnet source rocks as diamond sources, unless the

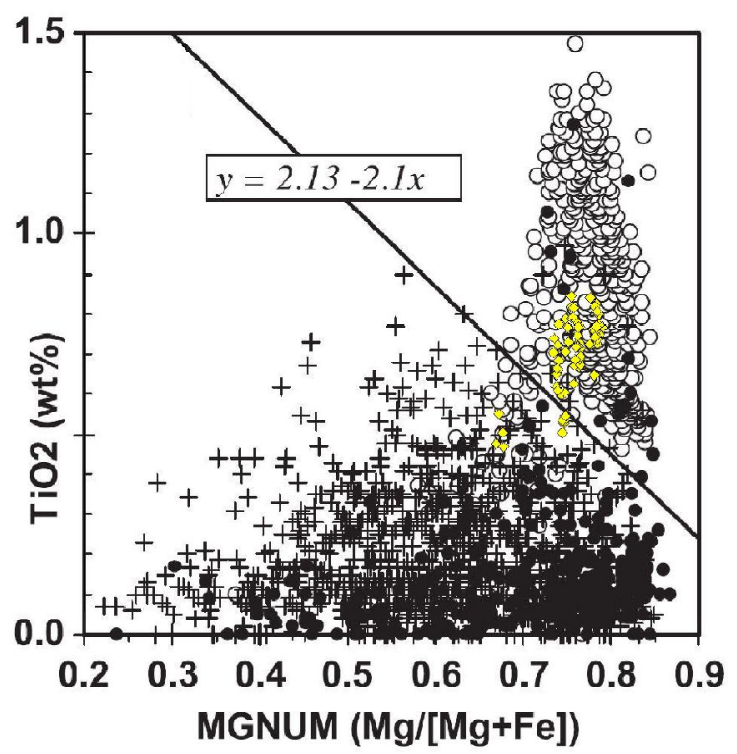

Figure 2. TiO2 versus magnesium number diagram for a large database of garnets $(n=2019)$ from kimberlite sources [Black dots pyroxenite, crosses $=$ eclogites, open circles $=$ megacrysts $]$ from Grütter et al., 2004. Line separates garnets of pyroxenite (below) and megacryst (above) compositions. Data for Liqhobong diamondiferous garnets (this paper, see Table 1) overlain as yellow diamonds.

Liqhobong example turns out to be a truly unique case. If it is not, then an additional diamondbearing rock type has been added to the list that must be considered in diamond evaluation studies.

\section{References}

Grütter, H.S., Gurney, J.J., Menzies, A.H. \& Wintera, F., 2004. An updated classification scheme for mantle-derived garnet, for use by diamond explorers. Lithos 77, 841-857.

Meyer, H.O.A., Tsai, H. \& Gurney, J.J., 1979. A unique enstatite megacryst with coexisting CR-poor and CR-rich garnet, Weltevreden Floors, South Africa, in The Mantle Sample: Inclusion in Kimberlites and Other Volcanics, edited by F. R. Boyd and H. O. A. Meyer, pp. 279-291, doi:10.1029/ SP016p0279, AGU, Washington, D. C.

Schmickler, B., Jacob, D.E., Foley, S.F., 2004. Eclogite xenoliths from the Kuruman kimberlites, South Africa: geochemical fingerprinting of deep subduction and cumulate processes. Lithos 75, 173-207. 
Table 1. Representative Analyses of I iqhobong diamond-bcaring garnet and opx grains

\begin{tabular}{|c|c|c|c|c|c|c|c|c|c|c|c|c|c|c|}
\hline Comment & $\mathrm{SiO} 2$ & $\mathrm{TiO} 2$ & $\mathrm{Al} 2 \mathrm{O} 3$ & $\mathrm{Cr} 2 \mathrm{O} 3$ & $\mathrm{FeO}$ & $\mathrm{MgO}$ & $\mathrm{CaO}$ & $\mathrm{K} 2 \mathrm{O}$ & $\mathrm{Na} 2 \mathrm{O}$ & $\mathrm{V} 203$ & $\mathrm{NiO}$ & Total & mgit & cait \\
\hline GD-01 Opx & 57.01 & 0.16 & 0.79 & 0.09 & 7.94 & 31.97 & 0.82 & 0.00 & 0.19 & 0.03 & 0.07 & 99.08 & 0.88 & 0.02 \\
\hline GD-02 & 42.08 & 0.73 & 22.15 & 0.62 & 8.97 & 20.13 & 4.23 & 0.00 & 0.11 & 0.07 & 0.04 & 99.12 & 0.80 & 0.13 \\
\hline $\mathrm{GD}-5$ & 42.50 & 0.69 & 22.15 & 0.38 & 9.11 & 19.85 & 4.17 & 0.00 & 0.09 & 0.07 & 0.03 & 99.04 & 0.80 & 0.13 \\
\hline GD-06Opx & 56.89 & 0.20 & 0.81 & 0.09 & 7.49 & 32.85 & 0.83 & 0.00 & 0.15 & 0.03 & 0.08 & 99.42 & 0.89 & 0.02 \\
\hline (j) -06 & 41.95 & 0.69 & 22.41 & 0.64 & 9.70 & 19.48 & 4.39 & 0.02 & 0.07 & 0.07 & 0.03 & 99.44 & 0.78 & 0.14 \\
\hline GD-13 & 41.04 & 0.09 & 16.95 & 9.04 & 6.27 & 19.57 & 6.02 & 0.00 & 0.00 & 0.05 & 0.01 & 99.02 & 0.85 & 0.18 \\
\hline GD-1.5 & 41.75 & 0.74 & 22.34 & 0.85 & 8.76 & 20.73 & 3.75 & 0.00 & 0.08 & 0.13 & 0.01 & 99.14 & 0.81 & 0.12 \\
\hline GD-16 & 42.33 & 0.26 & 21.04 & 3.04 & 6.90 & 20.71 & 4.55 & 0.02 & 0.02 & 0.08 & 0.04 & 98.97 & 0.84 & 0.14 \\
\hline GD-18 & 42.30 & 0.66 & 22.50 & 0.57 & 9.65 & 19.51 & 4.02 & 0.02 & 0.12 & 0.10 & 0.03 & 99.48 & 0.78 & 0.13 \\
\hline GD-20 & 41.93 & 0.74 & 22.29 & 0.16 & 10.74 & 18.80 & 4.22 & 0.00 & 0.07 & 0.09 & 0.01 & 99.05 & 0.76 & 0.14 \\
\hline
\end{tabular}

